\title{
SOME GROSS ANATOMICAL STUDIES ON THE EXTERNAL ACOUSTIC MEATUS AND CARTILAGES OF THE EXTERNAL EAR IN THE RABBIT
}

\author{
Farag, F.M.M
}

\begin{abstract}
This work was carried out on the heads of ten apparently healthy rabbits of various age and sex. The available literatures dealing with the gross anatomy of the external ear of various species of domestic animals were reviewed. The Manual dissection as well as the dry skull specimens were used according to the purpose under investigation. A comprehensive description of the external acoustic meatus as well as the various cartilages of the external ear was done. The results obtained were discussed with those recorded on the corresponding scopes in the other species of the domestic animals.
\end{abstract}

\section{INTRODUCTION}

The study of the anatomy of the rabbit in the last years attracted the attention of many investigators .The ear of all higher mammals composed of three divisions namely the external, middle and internal ear. These anatomical divisions serve to play two important functions; the hearing as a special exteroceptive sense of the cochlear division and equilibrium as a special proprioceptive sense of the vestibular division (Jenkins, 1972). However the auricle of the external ear plays an important role in collecting more sound waves through its movement. It also tagged, notches or tattooed for the identification of the animal. Moreover, the external ear is often exposed to many surgical problems as 
wounds, laceration and broken cartilage. The available literatures dealing with the study of the external ear of the rabbit were restricted to those given by Thakur/Puranik (1984) and Osman (1989). The present study is therefore an attempt to give an information about the anatomy of the external ear of this animal.

\section{MATERIAL AND METHODS}

The current investigation was carried out on the heads of ten apparently healthy rabbits of various age and sex.. Five of these heads were used to prepare the dry skulls needed to study the osseous part of the external acoustic meatus.In these specimens the skin and superficial muscles were removed as possible and then the heads were macerated in hydrochloric acid (40\%) for 2-3 days for corrosion. Lastly, the specimens were gently washed in running tap water until became free from the soft tissue and then let to dry. The remaining five specimens, were freshly dissected to investigate and separate the various cartilages of the external ear as well as for the investigation of the cartilaginous external acoustic meatus .The nomenclature adopted by the Illustrated Veterinary Anatomical Nomenclature (1992) as well as the Nomina Anatomica Veterinaria (2005).

\section{MEATUS ACUSTICUS EXTERNUS}

\section{RESULTS}

The. external acoustic meatus is represented by the canal leading from the base of the auricle to the tympanic membrane. It consists of an osseous and a cartilaginous part. 
The osseous part (fig. 1,2/1) is in the form of short conical bony canal about $1.5 \mathrm{~cm}$ in length. It extends ventromedially with slight rostral inclination. The diameter of the external acoustic meatus is maximum at its external orifice, the Porus acusticus externus (fig.1,2/2), where it measures about $0.8 \mathrm{~cm}$, while it gradually diminishes in its caliber as it

proceeds ventrally until it terminates with a tapered blind end. However, the internal orifice of the meatus, Osseous anulus tympanicus (fig. 1,2/3) lies in the medial wall of the meatus just above its fundus .It is in the form of a nearly circular orifice measuring about $0.4 \mathrm{~cm}$ in its diameter and it leads directly into the Cavum tympani (fig.2/4). In the fresh specimens this orifice is closed with the tympanic membrane (Ear drum).

The cartilaginous part, the Meatus acusticus externous cartilaginous (fig.2/5) is represented by by a short nearly circular incomplete cartilaginous ring, with its edges come in contact medially. It is wider but slightly shorter than the osseous part of the meatus measuring about 1.2 $\mathrm{cm}$ in length and $1.0 \mathrm{~cm}$ in its diameter. Its lower part embraces the bony edge of the Porus acusticus externus while its upper part is embraced by the annular cartilage to which it connects by an annular ligament.

\section{DISCUSSION}

In accordance with Dyce/Sack/Wensing(1987) and Schaller(1992) in domestic animals, the external ear was formed of the auricle and the external acoustic meatus and that the latter meatus was represented by the canal leading from the base of the auricle to the tympanum and it consisted of an osseous and a cartilaginous part. However ,the present results as wll as those given by Sisson (1975) in the horse revealed that the osseous part of the external acoustic meatus was in the form of short 
bony canal, wide at its entrance and was gradually diminished as it proceeds distally. On the other hand, Osman (1989) in the same animal stated that the osseous part was formed of a bony ring which was incomplete medially and added that it had the same diameter along its entire length . Moreover the latter author added that it extended distally in a vertical direction, an observation which could not be assertained in the present work in which the osseous part was extended ventromedially with rostral inclination. In this connection Gandhi (1975) in the ruminants recorded that the meatus was directed straight, medially while Handson/Hamilton (1993) in the cat stated that the meatus was directed ventromedially. On the other hand Dyce et al (1987) mentioned that the meatus in the dog proceeded at first ventrally then it curved rostromedially

while Sisson (1975) in the horse reported that the meatus was first directed medially,then ventrally and slightly rostrad.

The observation made by Osman (1989) in the rabbit that, the cartilaginous external acoustic meatus constituted the annular cartilage and the surrounding portion of the auricular cartilage could not be ascertained in the present study in which the Cartilago meatus acustici was represented by an independent incomplete cartilaginous ring , interposed in between the distal end of the annular cartilage and the osseous external acoustic meatus.

It is worthy to mention that due to the slight difference in the direction of the cartilaginous and osseous parts parts of the external acoustic meatus, in using the otoscope in the rabbit it is advised to pull the ear at first caudally, downward, with slight lateral inclination then rewind upward while the otoscope was advanced. 


\section{CARTILAGES OF THE EXTERNAL EAR}

\section{RESULTS}

\section{Auricula:}

The auricle (fig. 3/1) is the externally visible part of the ear and is formed mainly by the auricular cartilage, covered with skin at both surfaces. Its shape in the proximal (lower) quarter is rolled up forming a nearly cylindrical funnel shaped tube while the distal (upper) three quarters acquire the shape of a curved leaf like plate. It measures about 8.0-12 cm in length, while its breadth varies along its length .It is widest at its middle, where it measures about $3.5-5.0 \mathrm{~cm}$ and narrows at the upper and lower parts. In rest, the opening of the auricle faces laterally , while its convexity lied medially. Its longitudinal axis extends in a caudodorsal direction with slight lateral inclination. However, with any sound the auricle soon reflexes and the direction of its opening as well as its long axis changes, like an antenna.

The external ear comprises a framework of cartilages which are the auricular, scutiform and annular.

\section{Cartilago auriculae:}

The auricular cartilage is the largest of the cartilages forming the external ear and is responsible for the shape of the auricle .It consists of a thin and

pliable cartilaginous plate and can be described as having an apex and a base, two surfaces; medial or the dorsum and lateral or the scapha as well as the border or Helix. 
The Apex auriculae (fig. 3,4,5,6,7/2) constitutes the thin distal tip of the auricular cartilage and is formed at the junction of its rostral and caudal borders forming either a rounded (Fig. 4) or pointed (Fig. 5) angle.

The base (fig. $3,4,5,6,7 / 3$ ) is represented by the proximal, relatively thicker and less pliable end of the auricular cartilage. It is rolled up forming a sort of ring wich is incomplete laterally, and presents deep notch medially. It is completely concealed with the auricular muscles ,parotid gland as well as surrounding adipose tissue.

The Dorsum auriculae (fig. 3, 5/4) is the medial surface which is strongly convex from side to side and slightly convex from the base to the apex. The proximal part of the dorsum, is strongly rolled forming the wall of the cylindrical portion of the auricular cartilage and is reffered $t$ as the Concha auriculae(fig.4,5/5). The latter concha forms caudolateral bulge the, Eminentia conchae (fig.4,5/6) indicating the change in the direction of the lumen.

The Scapha (fig. 3,4,6,7/7) is the lateral concave surface of the auricular cartilage. It is concave from side to side at its distal portion while proximally it forms a funnel shaped cylindrical cavity, the, Cavum conchae (fig.4,7/8) which represents the lumen of the Concha auriculae. The skin lining the scapha presents no folds or ridges. However in five of the examined specimens the scapha presents an oblique low ridge, the plica scaphae (fig. 4/9).

The Helix (fig. 4/10) is the free margin of the auricular cartilage passing over the apex. It comprises the two borders of the latter cartilage; a rostral (Tragic) and a caudal (Antitragic) border. 
Margo tragicus (fig. 3,4,5,6,7/11) is the rostral border of the auricular cartilage and is covex along its length from the base to the apex and relatively thicker than the caudal one. Its distal end converge with the corresponding part of the caudal border, forming the apex of the auricular cartilage, while its proximal part is rolled caudolaterally forming an elongated prominence, the Tragus (Fig.4,6,7/12). Just above the latter, the Margo tragicus gives off two branches namely the Crura helices; medial and lateral which extend along the rostrolateral margin of the Cavum conchae.

The medial crus of the helix ,the Crus helices mediale (Fig.7/13) extends proximally for about $1.5 \mathrm{~cm}$ then curved medially forming a transverse ridge, the Antihelix (fig. 7/14) which unites with the medial wall of the Cavum conchae and divides the latter cavity into two portions; rostral and caudal. The rostral portion of the Cavum conchae is more roomy and blind distally forming a rostral marginal pouch, the Saccus cutaneous marginalis (fig.4,5,6,7/15). While the caudal portion (fig,7 /16)is narrow and continues the proximal course of the conchal cavity.

The lateral crus of the helix, Crus helices laterale (fig. 7 /17) extends caudlaterally being separated from the tragus by a deep notch, the pretragic notch, or Incisura pretragica (fig. 7/18) and come to lie in contact with the inner surface of the antitragus.

Margo antitragicus (fig. 3,4,5,6,7 /19) represents the caudal border of the auricular cartilage. It is concave proximally and convex distally and is thinner than the rostral one. The proximal part this border gives arise to a well quadrilateral cartilaginous plate , the Antitragus (fig. 4,6,7 120) which is demarcated dorsally from the rest of the antitragic border by a deep notch, the Incisura antitragohelicina (fig. 4,6/21). The upper Kafrelsheikh Vet. Med. J. Vol. 6 No. 2 (2008) 
part of the antitragus is separated from the tragus by a deep notch, the Incisura intertragica (fig. 4, 6/22), while its lower part extends rostrally and come to lie in contact with the adjacent part of the tragus laterally and the crus helicis lateralis, medially forming together the medial boundary of the cartilaginous tube surrounding the annular cartilage. From the upper portion of the antitragicus extend two processes, passing caudally into the Cavum auriculae. These processes comprise the Processus antitragicus lateralis (fig. 7/23) which extends on the lateral wall of the cavum auriculae close to the antitragic border and Processus antitragicus medialis (fig. 7 /24) which proceeds along the medial wall of the latter cavity. From the proximal end of the antitragic border project two processes separated by a shallow notch. The caudal process projects caudoventrally forming a prominent process which is designated as tail of the helix ,the Cauda helices (fig. 4,5,6/25) while the rostral one is the styoid process, Processus styloieus (fig. 6/ 26) which represented by a short pointed process ,about $1.0 \mathrm{~cm}$ in length that extends rostrally covering the caudolateral aspect of the annular cartilage.

\section{Cartilago scutiformis:}

The scutiform cartilage lies on the temporalis muscle along the medial aspect of the the base of the auricular cartilage.It is interposed in the course of some of the extrinsic muscles of the ear. It is in the form of a triangular cartilaginous plate which has a base, an apex, two borders; medial and lateral, two angles; rostrolateral and rostromedial as well as two surfaces; Superficial and deep.

The base (fig. 8 /29) can be considered as the rostral border of the cartilage and it faces rostrolaterally on the level of the middle of the parietal bone. Its lateral half is thicker measuring about $3.0 \mathrm{~cm}$ in 
thickness and it join the lateral border at the rostrolateral angle (fig. 8 130), while the medial half is relatively thin and join the medial border at the rostromedial angle (fig. 8/31).

The apex (fig. $8 / 32$ ) is the pointed most caudal part of the scutiform cartilage which is formed by the convergence of medial and lateral borders and it can be recognized as the caudal angle of the scutiform cartilage .It extended caudally to the caudal part of the base of the auricular cartilage on a level with the nuchal crest.

The medial border (fig. 8/ 33) is very thin and slightly convex along its length.It faces medially, being separated from its corresponding border of the scutiform cartilage of the other side by an interval of about $1.0 \mathrm{~cm}$, with the external sagittal crest extended in the middle of this interval.

The lateral border (fig. 8/34) is much thicker than the medial one and it lies in contact with the medial aspect of the base of the auricular cartilage. It measures about $0.5 \mathrm{~cm}$ in thickness and is concave along its length in conformity with the adjoin part of the auricular cartilage.

The superficial or dorsal surface (fig. 8 /35) is convex along its length as well as from side to side. On the contrary the deep or ventral surface (fig. 8 /36) is strongly concave in adaptation with the underlying M. temporalis

\section{Cartilago annularis:}

The annular cartilage (fig. 5,6,8/28) is represented by a short incomplete cartlaginous tube measuring about $3.0 \mathrm{~cm}$ in length and 0.8 $\mathrm{cm}$ in its diameter, with its edges overlaped at the medial part of the tube. The upper part of the annular cartilage is surrounded with a sort of cartilaginous ring formed by rolling of the proximal part of the base of

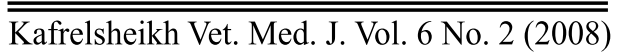


the auricular cartilage. The latter ring is bounded medially by the notch formed by base of the auricular cartilage, while the lateral margin is formed by the union of the tragus rostrally with the antitragus caudally. The lower part of the annular cartilage then, proceeds distally with slight rostromedial inclination and terminates by overlaping the cartilaginous external acoustic meatus with which it connects by an annular ligament. However a gentle ventral curve is formed at the junction of the annular cartilage with the Cartilaginous external acoustic meatus due to the slight difference in their the directions.

\section{DICUSSION}

In agreement with Omar/ Khidr / Selim (1983) in the camel, Sisson (1975) in the horse and ruminants, May (1970) in the sheep, Miller/ Christensen/Evan (1979) in the dog and Gandhi (1975) in the pig the external ear of the rabbit comprised a framework of cartilages which are the auricular, scutiform and annular.

The present study had revealed that, the proximal quarter of the auricle was rolled up forming a nearly cylindrical funnel shaped tube while the distal three quarters acquire the shape of a curved leaf like plate. However, in the rabbit, Wakuri (1984) stated that the upper half was somewhat piriform, while the lower was almost cylindrical, Thakur/ Puranik (1984) stated that it was trumpet-shaped flap, while Osman (1989) described it as a funnel shape. On the other hand, the shape of the auricle was described as an elongated oval in the sheep (May,1970), irregularly piriform or fan shaped in the pig and piriform or cylinder in the ruminants (Wakuri,1984).

In the rabbit, the opening of the auricle faced laterally similar to that reported by Ellenport (1975) in the dog and Sisson (1975) in the horse. However, Reighard/Jennings (1966) in the cat stated that it faced 
rostrolaterally, while May (1970) in the sheep recorded that it was directed rostrally. Moreover, Ellenport (1975) in the dog reported that the ear may face rostrally on one side and caudally on the opposite side at the same time. It is to add also that,the longitudinal axis of the auricle in the rabbit, was extended In a caudodorsal direction with slight lateral inclination .On the other hand, Sisson (1975) stated that it was vertical in horse and ruminants, while Gandhi (1975) in the pig reported that the direction of the auricle varied from vertical, inclined inward or even hanged ventrally.

The present results as well as those given by May (1970) in the sheep, Sisson (1975) in the horse and ruminants, Omar et al (1983) in the Camel and Kassab (1997) in both camel and donkey, revealed that the proximal part of the dorsum of the auricular cartilage was strongly convex forming the Eminentia conchae.

The current investigation revealed that, the scapha was smooth and presented no folds or ridges, except for only five specimens in which an oblique low ridge was demonstrated and could be favorably matched with the plicae scaphae recorded by Schaller (1992).

In the rabbit the rostral (tragic) border of the auricular cartilage and is convex along its length from the base to the apex, similar to that recorded by Omar et al(1983) and Kassab(1997) in the camel. However, the corresponding border was nearly straight in the dog (Ellenport, 1975), irregularly straight in the pig (Gandhi,1975) and sinuous in the horse (Sisson, 1975) and donkey (Kassab, 1997). It is to add that the Spina helices described by Schaller (1992) in canines and swines as a projection on the Margo tragicus could not be demonstrated in the rabbit. 
In greement with Schaller (1992) that proximal part of the tragic border is rolled caudolaterally forming the Tragus, while the corresponding part of the antitragic border gave arise to a well quadrilateral cartilaginous plate, the Antitragus. Similarly the tragus and antitragus were mentioned by May (1970) in the sheep, Ellenport (1975) in the dog, Sisson (1975) in the horse, Kassab (1997) in the camel and donkey. On the other hand Omar et al (1983) stated that no tragus and antitragus in the camel.

The present findings as also those recorded by Osman (1989) in the same animal showed that The rostral portion of the Cavum conchae formed a rostral marginal pouch, the Saccus cutaneous marginalis. However, Scaller (1992) mentioned that the corresponding pouch in Carnivora was formed on the antitragic border and added that only its rostral wall supported by cartilage.

In accordance with the statement of Scaller (1992) the antitragus gave off two processes, the Processus antitragicus lateralis et medialis which extend along the corresponding wall of the Cavum conchae. However the medial process could be matched with the crus antihelices recorded by Wakuri (1984) in the domestic animals It is to add that the Plica antitragica described by the latter author as well as by Scaller (1992) in canine as a skin fold passing proximally from the antitragus could not be observed in the rabbit.

It is also relevant to point out to the auricular model recorded by Wakuri (1984) in the domestic animals concluded the antihelix in monkey was formed by the conjunction of the crus antihelices with the Plica antitragica.Such conjunction was not observed in other domestic animals in which the antihelix was in the form of an imperfect low transverse ridge. Similar ridge was observed in the rabbit representing Kafrelsheikh Vet. Med. J. Vol. 6 No. 2 (2008) 
the antihelix and was formed by the continuation of the Crus helices medialis. The auricular model comprised also that there are two noticeable processes in the Cavum conchae. One of them is the tubercle on the top structure of the crus helices medialis the other one was a ridgy structure between the antihelix and the Crus helices medialis and this termed Crus cymbae However the tubercle could not be observed in the rabbit, while the Crus cymbae could be matched with the transverse ridge representing the antihelix.

The present investigation have shown that the styloid process was represented by a short pointed process, about $1.0 \mathrm{~cm}$ in length that extends rostrally covering the caudolateral aspect of the annular cartilage. On the other hand the latter process was a tubular structure directed ventromedially in the camel (Omar et al,1983), narrow pointed prolongation about $2.5 \mathrm{~cm}$ that project ventrally in the horse (Sisson,1975) and short and blunt in the ruminants (Sisson,1975) and in the sheep (May ,1970).

The current investigation showed that the scutiform cartilage was in the form of a triangular plate. On the other hand, the cartilage was described as a slender rod in the cat (Reighard /Jennings, 1966), a quadrilateral plate in the sheep (May, 1970), horse and ruminants (Sisson,1975), rabbit (Osman, 1989) and in both camel and donkey (Kassab, 1997), boot like cartilaginous plate in the dog (Ellenport, 1975) and pig (Gandhi,1975). It is to add that Omar et al (1983) in the camel stated that the shape of the scutiform cartilage was triangular, irregularly quadrilateral or nail like shaped. The observation made by the Sisson (1975) in the horse that the medial angle of the caudal part is prolonged by a pointed caudal process ,about $2.0 \mathrm{~cm}$ in length could be matched favorably with the apex of the cartilage observed in the rabbit. 
The present work recorded that the scutiform cartilage was extended along the medial aspect of the base of the auricular cartilage. However the scutiform cartilage was situated either on the rostromedial aspect of the base of the auricular cartilage as recorded by Gandhi (1975) in the pig and Omar et al (1983) in the camel or rostral to the latter cartilage as revealed by Reighard /Jennings (1966) in the cat, May (1970) in the sheep and Sisson (1975) in the horse. May (1970) add that it lied in between base of the horn and the auricle in the horned breeds.

It is relevant to point out that the statement of Osman (1989) in the rabbit, that the scutiform cartilage acts as sesamoid cartilage interposed on the course of the auricular muscles could be favorably accepted and it may be also suggested that it plays the role of a booster to the movement of the auricle.

In accordance with the observation of Bradley/Grahame(1947)and Sisson (1975) in the horse ,Omar et al (1983) in the camel and Kassab (1997) in both camel and donkey, the annular cartilage of the rabbit was in the form of an incomplete cartilaginous ring, while Miller et al (1979) in the dog stated that the annular cartilage formed a complete tube. However, in the rabbit the edges of the cartilage lied in contact medially, similar to that recorded by Raghavan/Kachroo (1964) in the ox .

\section{Legends for figures (1-2):}

1. osseous part of the_Meatus acusticus externus

2. Porus acusticus externus

3. Osseousanulus tympanicus

4. Cavum tympani.

5. Meatus acustisus externous cartilaginous

6. Bulla tympanic 


\section{Legends for figures ( 3-8):}

1. 1.Auricula.

2. Apex auriculae

3. The base of the Cartilago auriculae

4. Dorsum auriculae

5. Concha auriculae

6. Eminentia conchae

7. Scapha

8. Cavum conchae

9. plica scaphae

10. The Helix

11. Margo tragicus

12. Tragus

13. Crus helices mediale

14. Antihelix

15. Saccus cutaneous marginalis

16. caudal portion

17. Crus helices laterale

18. Incisura pretragica

19. Margo antitragicus

20. Antitragus
21. Incisura antitragohelicina

22. Incisura intertragica

23. Processus antitragicus lateralis

24. Processus antitragicus medialis

25. Cauda helices

26. Processus styloieus

27. Cartilago scutiformis

28. Cartlago anularis

29. base of scutiform cartilage

30. rostrolateral angle

31. rostromedial angle

32. Apex

33. medial border

34. lateral border

35. superficial surface

36. deep surface

37. osseous part of the Meatus acusticus externus

38. Meatus acustisus externous cartilagineus.

39. Bulla tympanicaa 


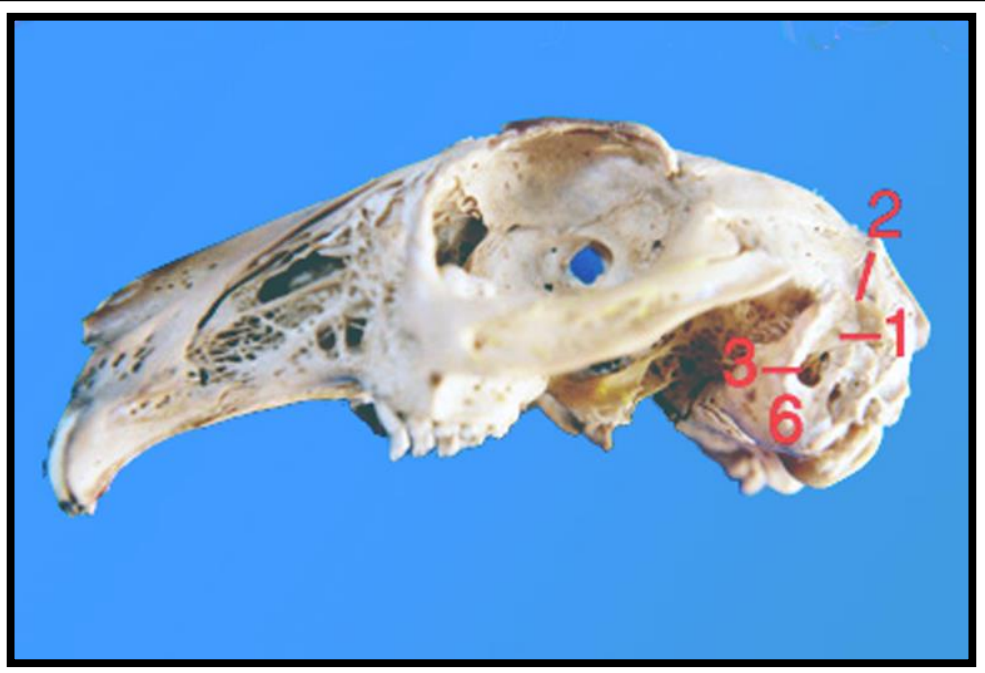

Fig (1): Photograph for the lateral view of the skull of the rabbit showing the osseous external acoustic meatus. The lateral wall of the meatus was cut.

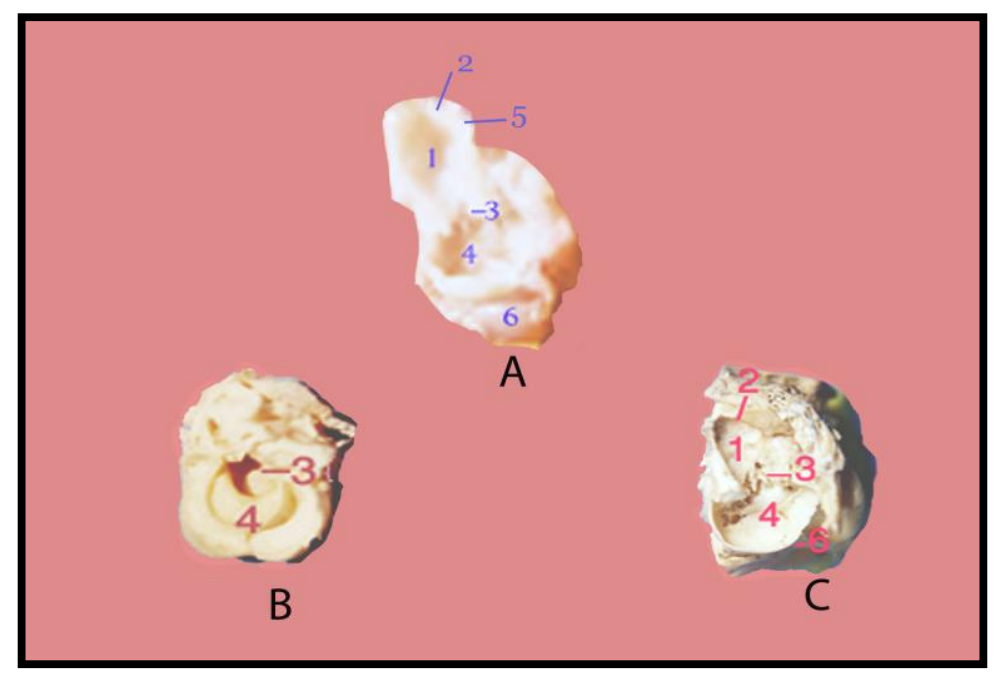

Fig. (2): Photograph showing the external acoustic meatus and tympanic cavity of the rabbit.
A. fresh specimen. The lateral wall of the meatus and Bulla tympanica were cut
B. Bony specimen The medial wall of the Bulla tympanica was cut.
C. Bony specimen. The lateral wall of the meatus and Bulla tympanica were cut. 


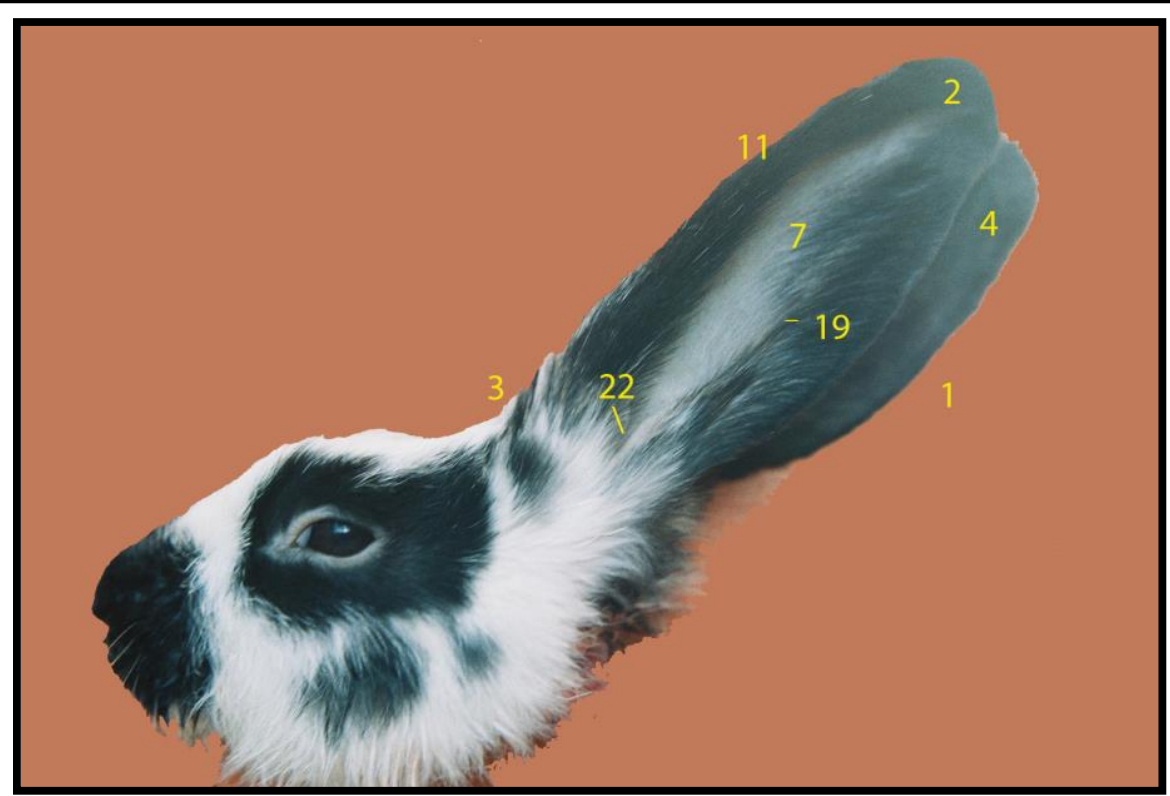

Fig. (3): Photograph showing the lateral view of rabbit head showing the auricle.

Fig. (4): Photograph showing the lateral view of the auricular cartilage.

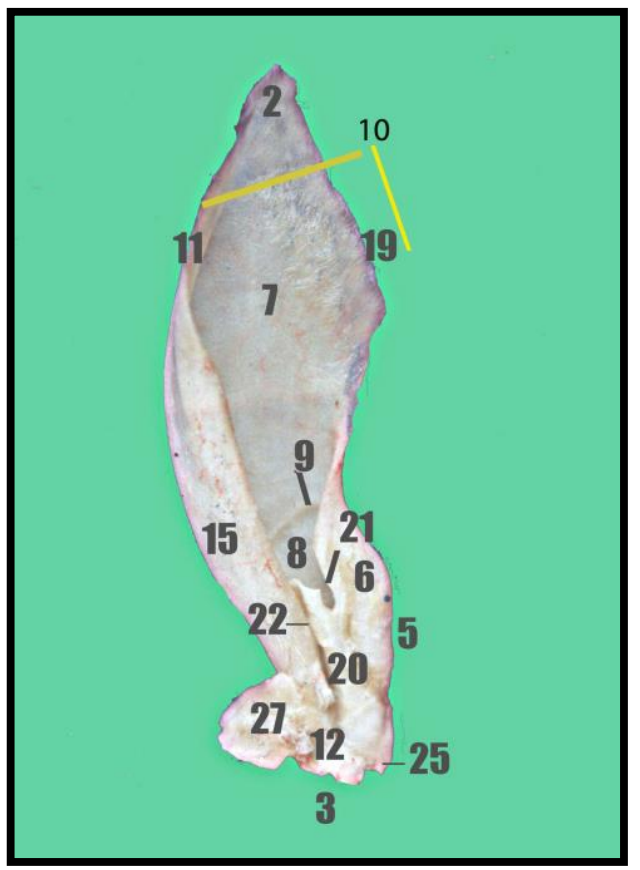


Fig. (5): Photograph for the
A. Medial view of the auricular cartilage .
B. Dorsal view of scutiform cartilage of the rabbit.

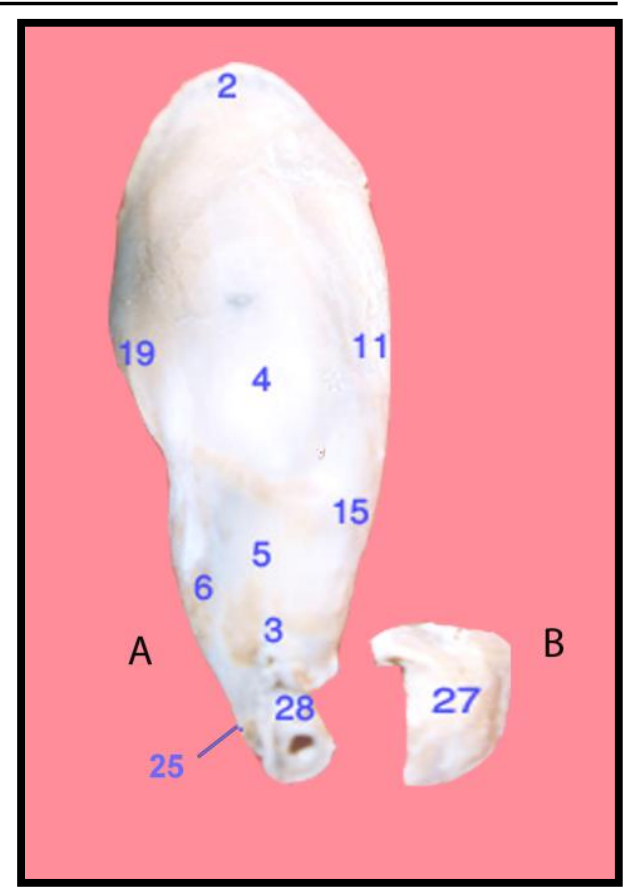

Fig. (6): Photograph showing the lateral view of the cartilages of the external ear, external acoustic meatus and bulla tympanica of the rabbit.

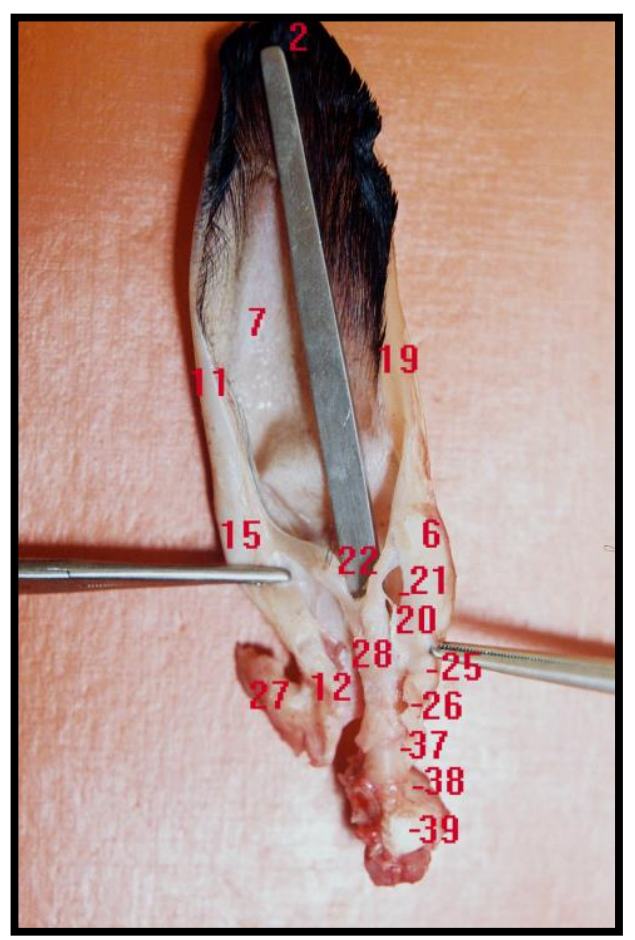


Fig (7): Photograph showing the lateral view of the auricular cartilage of the rabbit. The borders were pulled out to expose the Cavum conchae.
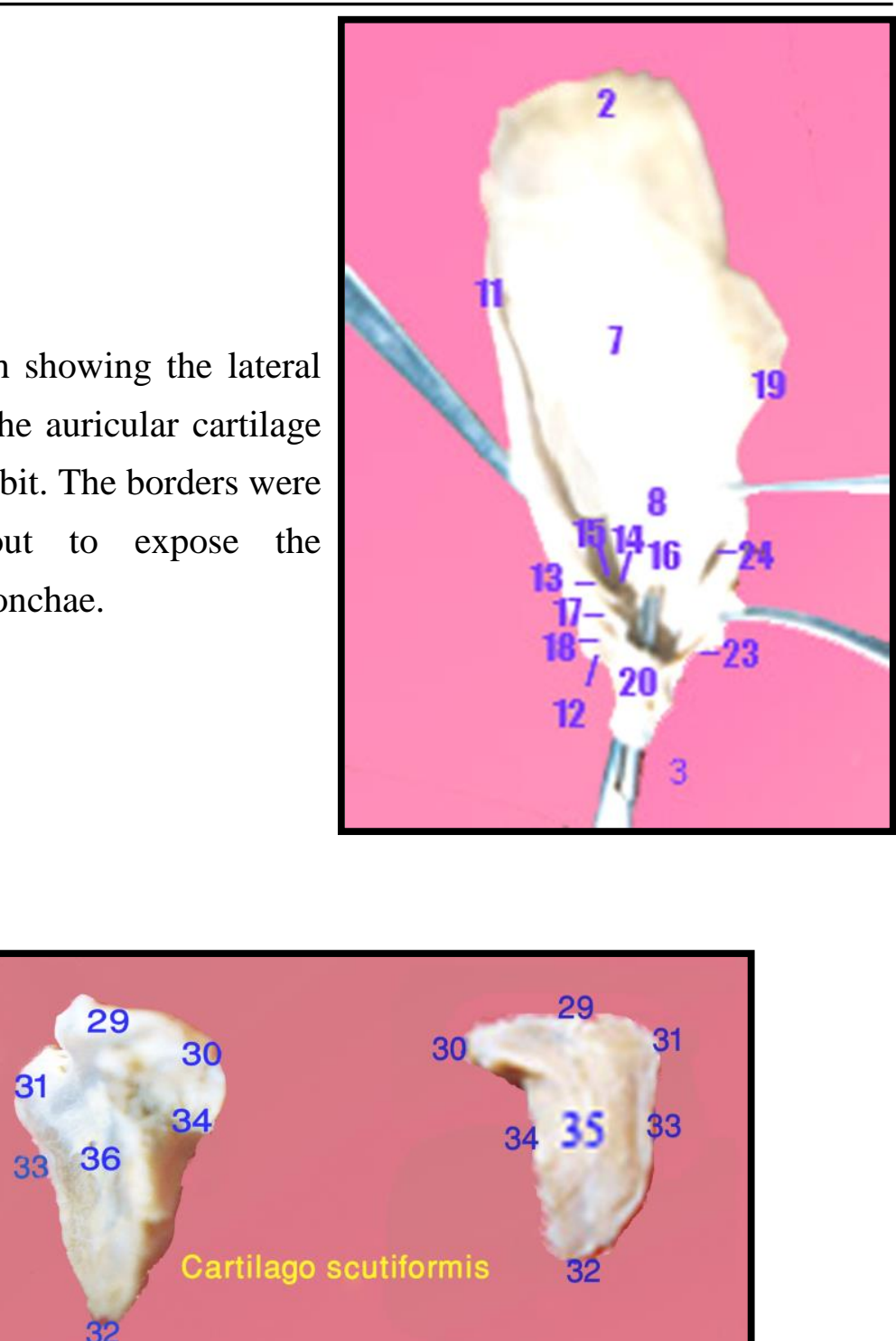

Ventral view

Fig. (8): Photograph showing the scutiform and annular cartilages of the rabbit. 


\section{REFERENCES}

- Bradley, O.C. and T. Grahame (1947): The topographical anatomy of the head and neck of the horse. 2nd edition, Edinburgh, W. Green and Son, limited.

- Chauveau, A. and S. Arloing (1891): Comparative anatomy of the domesticated animals, $2^{\text {nd }}$ edition, London J. \& A. Churchill.

- Dyce, K.M.; W.O. Sack and C.J.G. Wensing (2002): Textbook of Veterinary anatomy, $3^{\text {rd }}$ edition, W. B. Saunders Company, Philadelp-hia. London.

- Ellenport,C.R. (1975): The ear of carnivores. In Sisson and Grossman, the anatomy of the domestic animals by Getty,R. $5^{\text {th }}$ Ed. W.B. Sound-ers Co. Philadelphia, London, Toronto.

- Gandhi (1975): Ruminant and Swine middle ear and auricular muscles. In Sisson and Grossman, the anatomy of the domestic animals by Getty, R. $5^{\text {th }}$ Ed. W.B. Sounders Co. Philadelphia, London, Toronto.

- Jenkins,T.W. (1972): Functional Mammalian neuroanatomy with emphasis on dog and cat. Lea and Febiger. Philadelphia.

- Kassab, A.A.M. (1997): Comparative anatomical studies on the external ear of the camel (Camelus dromedarius) and donkey (Equus asinus). M.V.Sc. Thesis, Benha faculty of Veterinary Medicine, Zagazig University, Egypt. 
- May,D.S.N. (1970): The anatomy of the sheep . $3^{\text {rd }}$ ed.Univ. of Queensland press. Brasibane. Australia.

- Miller,M.E., Christensen,G.C. and Evans,H.E. (1979): Anatomy of the $\operatorname{dog} .2^{\text {nd }}$ Ed. W.B. Saunders Comp. Philadelphia,London.

- Nomina Anatomica Veterinaria (2005): $5^{\text {th }}$ edition. Prepared by the international Committee on Veterinary Gross Anatomical Nomenclature (I.C.V.G.A.N) and authorized by the General Assembly of the World Association of Veterinary Anatomists (W.A.V.A.), Knoxville, TN (USA). Published by the Editorial Committee, Hannover, Columbia, Gent, Sapporo.(Electronic version).

- Omar,A., Khidr,I. And Selim, A. (1983): The cartilages of the external ear of the one humped camel (Camelus dromedarius) Egypt. J. Anat.Vol.7.

- Osman F.A. (1989): Some gross anatomical studies on the ear of the rabbit; part 1: External ear. Alex. J. Vet. Sci. Vol.5, No. 1.

- Raghavan, D. and P. Kachroo (1964): Anatomy of the ox with comparative notes on horse, dog and fowl. $1^{\text {st }}$ edition. Indian council of Agricultural Research, New Delhi, India.

- Reighard,J. and Jennings,H.S.1966): Anatomy of the cat. Michigan University. 
- Schaller,O. (1992): Illustrated Veterinary Anatomical Nomenclature. Ferdinand Enke Verlag Stuttgart.

- Sisson, S. (1975): Equine digestive system in Getty, R.: Sisson and Grosman's - The anatomy of the domestic animals. $5^{\text {th }}$ edition, vol. I \& II, W. B. Saunders Company, Philadelphia. London.

- Thakur,R.S. and Puranik, P.G. (1984): Rabbit, a mammalian type S. chand and Company Ltd. Ram Nagar , New delhi.

- Wakuri, H. (1984): A morphological study on the concave contour of the auricle of domestic mammals. Kitasato Archives of experimental medicine, Vol.57,No. 1.

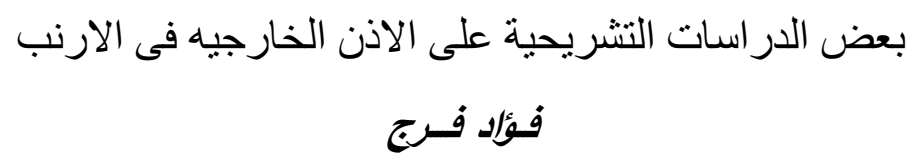

قسم التشريح - كلية الطب البيطري - جامعة القاهرة

أجرى البحث على رؤوس عشره من الأرانب المختلفة الأعمار والجنس. وقد استخدمت خمسه

منها لتحضير العينات الجافة اللازمة لدراسة الدهليز السمعي الخارجي, وقد استخدت الخمسة رؤوس أخرى لفصل ودراسة غضاريف الأذن الخارجية وكذا غضروف الدهليز السمعى الخارجي. وقد بينت الدراسة الوصف النتريحي لدهليز الأذن الخارجية بجزئية العظمى والغضروفي ,وكذا غضاريف الأذن الخارجية الثلاث وهى الغضروف الصيوانى، الغضروف الدرعى والغضروف الحلقي.وقد تمت مناقثة $\overline{\overline{\text { Kafrelsheikh Vet. Med. J. Vol. } 6 \text { No. } 2 \text { (2008) }}}$ 
النتائج التي نم الحصول عليها مع مثلتنها في الحيوانات الأخري كما استخدت المصطلحات المتناولة فى المسميات التشريحيه اليبطريه (1992) والإصدار الإلكتروني لا . (2005). 